\title{
Geological- ecological- social- and economic approach to the development of natural resource potential of northern poorly known areas according to the system theory
}

\author{
A. I. Tatarkin, V. V. Balashenko, A. V. Dushin, M. N. Ignat'eva, A. A. Litvinova, \\ V. G. Loginov, I. G. Polyanskaya, A. I. Semyachkov, Yu. O. Slavikovskaya, V. V. Yurak
}

The results of the second year of research under the grant No 14-18-00456 (Russian Science Foundation) are reflected in the article. It is implemented under the leadership of Academician, Dr in Economics A. I. Tatarkin. As a result of the research we have developed consistent aspects of the geological- ecological- social- and economic approach from the consistency point of view. It demanded to address the system theory and explore the relationship between the natural and socio-economic subsystems within the ecological and economic system. Based on the identified trends we demonstrate the necessity of investment projects of the development of the natural potential (which is being developed in the framework of regional ecological and economic systems) that are oriented on the equilibrium of natural resource management. The natural resource management provides a balanced environmental capacity of the technosphere and ecological technology capacity of the area. Particular attention is paid to the ecological optimization of the landscape with the help of a network of special protected natural areas (SPNA). We have found the distinctive features of the modern Russian system of SPNA, detailed a list of ecosystem and resource functions within the different types of SPNA, systematized methodical approaches to the justification of the network of SPNA, improved methodological tools of economic evaluation of the lands with nature reserve purposes. We have also developed guidelines for the assessment of the environmental situation the territory, based on the excess of the actual components of the pollution indicators of the environment over the background or maximum allowable concentration. The second stage of evaluation procedures in respect of renewable natural resources providing an investment zoning is detailed. Based on the potential demand for natural resources we recommend allocating the seven typical landscaped areas, five of which are estimated in the article.

The program of group development of the prospect objects with mineral potential of the North Subpolar and Polar Urals is supplemented by the scenario and determined the size of a possible investment reduction from the beginning of the opening of a deposit. Completeness of institutional capacity in relation to Russia and Kazakhstan is estimated. We have identified the emerging social and environmental effects of the industrial and transport development of northern territories. The article offers a methodical approach of enlarged assessment of economic damage, based on the decrease in the economic value of natural resources under the influence of anthropogenic impact. Lines of possible balance between traditional and industrial natural resource management is formulated. We offer the methodological tools of assessment the comfort of living providing for the use of the scores in the zonal and azonal factors approved for areas within the prospective transport corridor. These studies are the basis for the construction of the optimization of economic and mathematical models aimed at the selection of variants of the natural potential development meeting the requirements of the equilibrium of natural resource management.

Keywords: consistency; development; network of special protected natural areas (SPNA); investment attractiveness; group development; effects; economic damage; comfort of living.

The second step of our research involves
the development of consistent aspects
of the geological- ecological- socialand economic approach from the consistent point of view. It demanded to address the system theory and explore the properties of complex natural systems and the evolution of the relationship between wildlife and human society (Fig.) [1]. We explore the ecological and social (EgS), social and ecological (SEg), economic and ecological (EEg) and the ecological and economic (EgE) relationships (Fig.). These relationships are shown in Table 1, from which it follows that during the period before the agrarian economy there was a natural balance in the relations between nature and society. Humanity was a part of nature, no labor functions performed by a person, his impact on nature (EgS) exceeded the natural limits, and it means that any negative effects were absent. At the stage of the agrarian economy a transition to a producing economy occurred, we had growing contradictions in the metabolic processes between the nature and society. Along with the relationships (EgS) social and ecological relationship was formed, which refl cted the gain on influence of nature on society as well as the influence of society on nature. At the same time we could see a weakening dependence of society from the effects of unconscious forces of nature. 


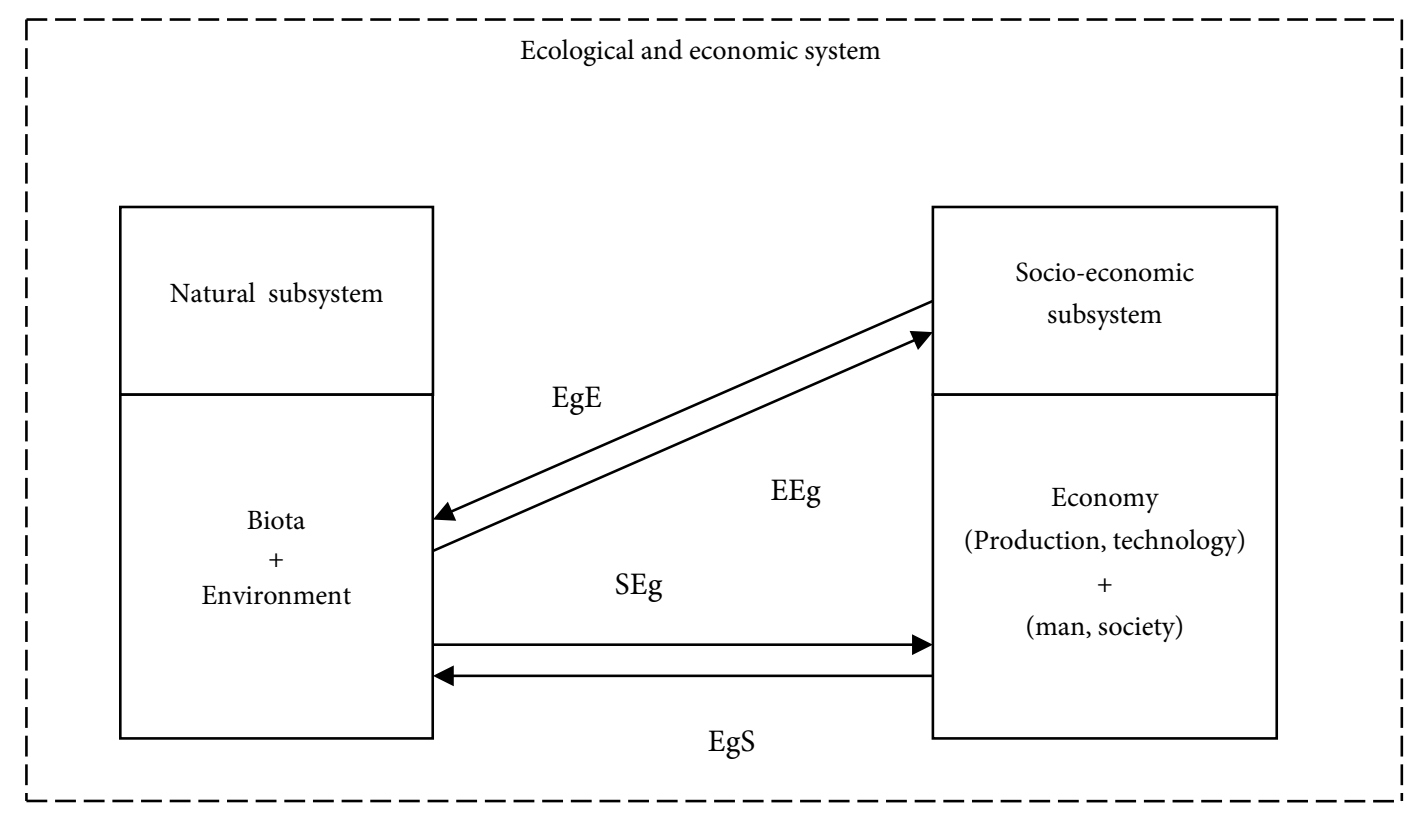

Relationships in the framework of ecological and economic system

At the stage of the front economy (capitalist society), an increase in imbalances in the exchange processes between nature and society continued, and later led to local and regional environmental crises. The impact on the environment (EgE) and the response from the nature (EEg) increased. In the public mind the recognition of the human omnipotence over nature was adopted. People distanced themselves from nature. Modifi d environment has been having a negative impact on health and human life since the beginning of the front economy. A certain reduction of anthropogenic impact of industrial activity on the environment through a series of environmental activities characterizes the environmental economy but due to extensifi ation of production and growth in the use of natural resources the impact (EEg) on the recipients, including a humans (SEg) is signifi ant.

Overcoming the environmental complications, a signifi ant decrease of anthropogenic impact and the response of the modifi $\mathrm{d}$ environment on the stage of the economy of the sustainable development (when we solve the problem of prevention of negative effects or signifi ant attenuation as a result of continuous monitoring of technogenesis) are made possible by in-depth investigation of the laws of functioning of biological systems, the creation of environmentally friendly technologies, comprehensive greening of our minds. At the stage of the economy of the progressive development it is expected that we will achieve a harmony in the "society-nature" system, provide a closed production process, include production in the boundaries of the "energy corridor" which will be created according to the basis of stability of the biosphere. The similar trend is also a characteristic of the relationships between human (society) and nature.

Investment projects for the development of natural resources prossesed on the stage of the economy of the sustainable development should be focused on the equilibrium of natural resource management, which requires balancing environmental capacity of the technosphere (production) and ecological technology capacity of the area, which are located within the boundaries of reclaiming natural resources. We have formulated the basic principles, which predetermine the requirement of taking into account an ecological factor with a refl ction of the specific characteristics of underdeveloped areas, which are considered as a prerequisite to ensure biosphere compatibility in the natural resource management. These include:

- the primacy of environmental goals in relation to the objectives of economic development;

- adding the use of natural resources with their protection under the system of special protected natural areas (SPNA), conservation of landscape and biological diversity through the formation of natural and ecological frame of the territory;

- early warning of the negative environmental impacts and guarantee of their minimization by the environmental diagnostics of the area during the execution of which we assess the quality of the environment and landscape resilience to human impacts. Accounting the landscape and environmental features of the area at the stage of pre-project research allows to more reasonably predict the possible consequences and to exercise a control over the anthropogenic load; 
Table 1 | Development models of economy and the nature of the relationships in the Ecological and Economic System (EgES)

\begin{tabular}{|c|c|c|c|}
\hline $\begin{array}{l}\text { Type of the development } \\
\text { model of economy }\end{array}$ & $\begin{array}{l}\text { Relationships in the "society-nature" } \\
\text { system }\end{array}$ & Terms of economic development & $\begin{array}{l}\text { Functioning } \\
\text { relationship }\end{array}$ \\
\hline $\begin{array}{l}\text { Before the agrarian } \\
\text { economy }\end{array}$ & $\begin{array}{l}\text { Harmonious relations in nature, } \\
\text { passive human adaptation to } \\
\text { nature }\end{array}$ & Assigning economy & EgS \\
\hline Agrarian economy & The moral concept of man & $\begin{array}{l}\text { Generating economy (agrarian, } \\
\text { before capitalist society) }\end{array}$ & $\begin{array}{l}\mathrm{EgS} \rightarrow \\
\mathrm{SEg} \rightarrow\end{array}$ \\
\hline Front economy & $\begin{array}{l}\text { The concept of human } \\
\text { omnipotence }\end{array}$ & $\begin{array}{l}\text { A devastating biological and } \\
\text { mineral resources consumption }\end{array}$ & $\begin{array}{l}\mathrm{EgE} \Rightarrow \\
\mathrm{EEg} \Rightarrow \\
\mathrm{SEg} \Rightarrow \\
\mathrm{EgS} \Rightarrow\end{array}$ \\
\hline Environmental economy & $\begin{array}{l}\text { The concept of nature } \\
\text { conservation }\end{array}$ & $\begin{array}{l}\text { Elimination or reduction the } \\
\text { impact on the environment }\end{array}$ & $\begin{array}{l}\leftarrow \mathrm{EgE} \\
\leftarrow \mathrm{EEg} \\
\leftarrow \mathrm{SEg} \\
\leftarrow \mathrm{EgS}\end{array}$ \\
\hline $\begin{array}{l}\text { Economy of the } \\
\text { sustainable development }\end{array}$ & $\begin{array}{l}\text { The concept of the unity of man } \\
\text { and nature, the equilibrium of } \\
\text { natural resource management }\end{array}$ & $\begin{array}{l}\text { Long-term development in the } \\
\text { framework of environmental } \\
\text { restrictions aimed at preserving } \\
\text { the ecological balance }\end{array}$ & $\begin{array}{l}\Leftarrow \mathrm{EgE} \\
\Leftarrow \mathrm{EEg} \\
\Leftarrow \mathrm{SEg} \\
\Leftarrow \mathrm{EgS}\end{array}$ \\
\hline $\begin{array}{l}\text { Economy of the } \\
\text { progressive development }\end{array}$ & $\begin{array}{l}\text { The concept of harmony } \\
\text { between man and nature }\end{array}$ & $\begin{array}{l}\text { Noospheric development and } \\
\text { building of an equitable world } \\
\text { order }\end{array}$ & $\begin{array}{l}\mathrm{EgE} \\
\mathrm{EgS}\end{array}$ \\
\hline
\end{tabular}

$\rightarrow$ Strengthening of the human impact and response from the modified nature

$\Rightarrow$ Significant strengthening of the human impact and response from the modified nature

$\leftarrow$ Decrease of the human impact and response from the modified nature

$\Leftarrow$ Significant decrease of the human impact and response from the modified nature

- accommodation and the development of material production on a particular area, in accordance with its environmental technological capacity, i. e. the comparison of environmental capacity of the technosphere and ecological technology capacity of the area with a gradual transition to the environmental regulations limiting the environmental capacity of the technosphere;

- preservation of traditional natural resource management as a basis for maintaining the traditional way of life, ethnic origin, cultural traditions of indigenous peoples through the provision of ethnic status territories [2].

As part of the formation of ecologically balanced regional structure, we pay a particular attention to the ecological optimization of the landscape with the help of a network of SPNA, the creation of which is considered as a socially signifi ant institution of survival for humankind. We have found the distinctive features of the modern Russian system of SPNA. We have also detailed a list of ecosystem and resource functions that are implemented in the natural reserves, national parks, nature reserves, partial reserve and natural monuments, which are interconnected with a list of tasks that could be solved with the help of special protected natural areas. We carried out in Table 2 the justifi ation of parks functions, taking into account the zoning of the latter (action area, specially protected area, zone of the traditional natural resource management, recreation zone and zone of economic purposes).

We have systematized the methodical approaches used to justify the creation of a network of SPNA that are combined into two main groups: natural and costly with an additional allocation of the third, mixed (combined) group, which takes an intermediate position and provides the use of tools from both the fi st and the second group. We define the first group of ecological and biological (biology-geography) approach, based on an assessment of the spread patterns of communities living together with plants, animals and microbes; and geological- and eco- 


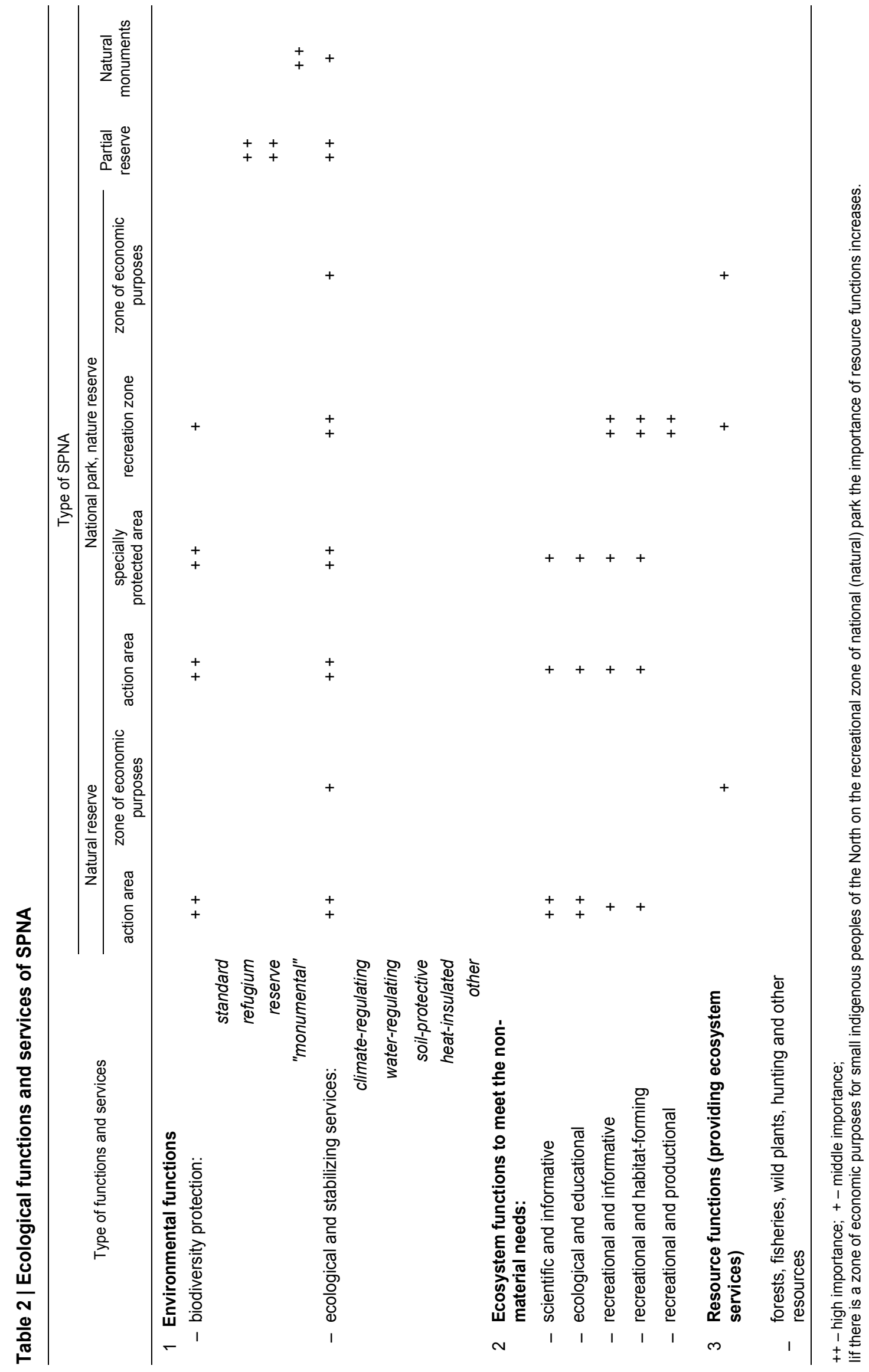


logical approach allows to consider SPNA through the relation prism of a natural, social, cultural, and economic components. The second group comprises the methodical approaches that provide a direct valuation of the flow of natural goods and services from SPNA. Mixed methodical approach is reflected in the teaching materials on the state cadastral valuation of land of natural reserves [3].

We have perfected the methodical tools offered in the "Feasibility Study of a technique of state cadastral valuation of land of natural reserves" (2002) for the economic valuation of land of natural reserve purposes. These tools are based on the calculation of the basic cadastral value (the average standard value) of the land at the Russian Federation level with following correction using scaling factors that take into account the implementation of biosphere functions by ecosystems. Proposes for specifi ation of technique concern the use of the annual index of standard average values of land of SPNA, expanding the list of objects of protection of rare species of plants and animals listed in the Red Book of the region. Proposes also concern the consideration of the environmental importance of SPNA refl cting the scale of ecosystems' rarity and conservation value of ecosystems, depending on its location in a functional area of SPNA. The technique was tested for the conditions of east macro slope of Northern and Polar Urals within the boundaries of Berezovskiy District KhantyUgra. We have formulated offers for the establishment of the network of SPNA in the Polar Urals YamaloNenets Autonomous District (YNAO) on the basis of the aggregated environmental assessment of all kinds of biotic components (fauna and hybrid biological complexes, soil and vegetation cover).
Ensuring of biosphere compatibility requires an objective assessment of the environmental situation of the territory, which explains the use of information that characterizes the state of the air, soil and surface water. The offered guidelines are based on the excess of the actual components of the pollution indicators of the environment over the background or maximum allowable concentration (MAC). We recommend performing ranking of the territory on the basis of a comprehensive grade indicator reflecting the state of the atmosphere, water and soil in terms of pollution. According to the guidelines we did a ranking of Berezovsky district of KhantyUgra, Priuralsky and Shuryshkalsky areas of YNAO.

Specific ty of the methodical approach to the evaluation of the stability of the landscape in relation to anthropogenic impact in terms of lack of information, as opposed to guidelines, which were developed earlier [4], provides an appeal to indicator of deer capacity that refl cts the presence of a phytomass indirectly. The integrated geographical- environmental assessment of the stability based on the recommended methodical approach has been made for the conditions of the study area in YNAO.

The second stage of evaluation procedures in respect of renewable natural resources providing an investment zoning is detailed based on the potential demand for natural resources. Ths approach demands some steps in a researching process.

We have offered an algorithm for implementing a methodical approach, disclosed the contents of each of the five stages. We have also formulated a list of factors to be considered during a justifying process for typical landscaped areas serving as a stan-

Table 3 | Indicators of investment attractiveness of renewable resources of landscape in Berezovsky District

\begin{tabular}{|c|c|c|c|}
\hline Type of landscape & Unit cost, ths RUR / ha. & Area, ths ha. & $\begin{array}{l}\text { Indicator of investment } \\
\text { attractiveness }\end{array}$ \\
\hline 1.1. Wetlands, upbeat & 1,64 & 350,3 & $\begin{array}{l}\text { B - attractive for investments } \\
\text { with restrictions }\end{array}$ \\
\hline 1.2. Wetlands, lowland & $\begin{array}{l}\text { Obviously the low } \\
\text { estimate }\end{array}$ & 1741,8 & C - unattractive for investments \\
\hline 2.1. Unproductive forest lands & 1,65 & 2931,1 & $\begin{array}{l}B \text { - attractive for investments } \\
\text { with restrictions }\end{array}$ \\
\hline 2.2. Productive forest lands & 6,03 & 1630,4 & A - attractive for investments \\
\hline $\begin{array}{l}\text { 3. Land is suitable for agricultural } \\
\text { purposes }\end{array}$ & $\begin{array}{l}\text { Obviously the low } \\
\text { estimate }\end{array}$ & 38,0 & $\mathrm{C}$ - unattractive for investments \\
\hline $\begin{array}{l}\text { 4. Other land is unsuitable for } \\
\text { economic activity }\end{array}$ & $\begin{array}{l}\text { Obviously the low } \\
\text { estimate }\end{array}$ & 146,6 & C - unattractive for investments \\
\hline 5. Productive wetlands & 3,33 & 46,0 & A - attractive for investments \\
\hline 6. Land with buildings and roads & Unestimated & 7,02 & - \\
\hline 7. Specially protected area & Forbidden for investment & 1918,8 & - \\
\hline
\end{tabular}


dard for comparative assessment of the landscapes.

For the northern poorly known areas, we recommend to allocate the seven typical landscaped areas, five of which are estimated in the article taking into account local capacities through methodical approach recommended in the research [5]. Detailed economic evaluation of the natural potential of typical landscapes demands an adjustment with scaling factors refl cting the results of the indirect assessment of ecosystem services and the location of landscapes in relation to transport infrastructure, industrial facilities and human settlements. Indicators of investment attractiveness of typical landscapes of Berezovsky District of Khanty-Ugra are shown in Table 3.

As follows from the analysis the most attractive landscapes for investment are productive forest land, it occupies $18.5 \%$ of the total area of the Berezovsky District, and unproductive forest land, located on the area, which occupies $33.3 \%$. Productive wetlands with the high value $-3,33$ ths RUR/ths ha. account for only less than $1 \%$ of the total area of Berezovsky district. We have identifi $d$ a structural ratio of value of the typical landscapes: attractive for investments areas - 19\%, areas that are attractive for investments with restrictions $-37.2 \%$, unattractive for investments areas $-22 \%$ and specially protected area $-21.8 \%$. Economic evaluation of environmental resources (ecosystem services) has been considered under the concept of total economic value. We have systematized the materials with estimations, supplemented and perfected a number of calculation formulas used to assess ecosystem services, conducted an economic assessment of ecosystem services in the regulatory aspect of classifying the types of landscapes.

The study reconfirms geological, mining and processing data on the projects, taking into account changes in environment, directions of regional industrial policy and changes in development priorities of mineral potential of the Northern, Subpolar and Polar Urals. The program of group development of the prospect objects in the natural resource management is supplemented by the scenario approach. Taking into account the updated geological, mining and processing data and the results of the industrial signifi ance evaluation for further research, and evaluation and development of the Northern and Polar Urals Khanty-Ugra, some objects have been selected, as follows: Dodo, KhusOyka, Zeyka ("Polar Quartz" Narodninsky potential mining sites) Tolinsky, Otoryinskoe, Verhnetolinsky (Otoryinskoe potential mining sites), Ust-Maninsky (Ust-Maninsky potential mining sites).

We have proved that the development of these objects should be done from two centers of socio-economic infrastructure: Saranpaul and Pripolyarny, in connection with the reduction in the number of prospects and priorities and changes in regional industrial development policy. As a result, we can select potential mining sites (PMS-I) on the area of Ural part of Khanty-Ugra:

Saranpaul PMS-I

- "Polar Quartz" (Dodo, Khus-Oyka, Zeyka);

- Lyulinsky (Borisov site);

- Yana-Turinsky

Pripolyarny PMS-I

- Tolinsko-Otoryinskoe;

- Verhneturinsky;

- Ust-Maninsky.

Comparison of technical and economic parameters for a single and group development of deposits has allowed assessing of the effectiveness of group development. Implementing the group development of mineral potential of solid minerals of Polar Urals YNAO reduces the amount of investment from the beginning of development by 820 mln RUR, in the framework of the development of mineral potential of Khanty-Ugra - by 1823 bn RUR. Completeness of institutional capacity in relation to Russia and Kazakhstan is estimated in terms of the developed technique [2]. An average level characterizing the deviation from the standard version was $23 \%$ - to Russia and $25 \%$ - to Kazakhstan. Directions of improving institutional capacity are justifi $\mathrm{d}$.

The study demonstrates the emerging environmental and social effects of the industrial and transport development of the territory. Consequences caused by anthropogenic impact on the recipients, primarily to components of the environment, which are the material basis of the traditional economies, are attributed to ecological effects. Based on the experience of the design and the results of the expert survey, we established the area falling under the influence of mining complexes within which we marked ecological zones with different degrees of decline in economic value of natural resources. When we were selecting zones, we took into account the stability parameters of landscapes and the degree of environmental hazard of objects. The research offers calculation formulas for evaluating the enlarged projected economic losses, based on the reduction of the value of natural resources, proven for mineral potential of Khanty-Ugra [6].

The study have found that the nature of the social consequences is extremely specific for the alien population and small indigenous peoples of the North. Lines of possible balance between traditional and industrial natural resource management are formulated. The social effects of the alien population include:

- deterioration of living conditions and health of rotation workers;

- damage caused by a low level of social infrastructure;

- retraining and migration costs.

We have formulated a defin tion of the social and industrial potential of the northern territory, 
justified its structure and methodical approach to the evaluation. We offer the methodological tools of assessment the comfort of living. These tools suggest usage of the zonal and azonal factors. The scores, which serve as the basis for selection of four types of areas according to the degree of comfort, are used for the assessment of the factors. Zoning and evaluation of the comfort of living is carried out for areas within the transport corridor and the eastern slope of the Northern, Subpolar and Polar Urals with the surrounding lowland areas stretching for $1000 \mathrm{~km}$ from the south to the north. The results of the ranking can be used in planning the location of future industrial centers as well as in the preliminary design of investment projects for developing natural resources.

These studies are the basis for the construction of the optimization of economic and mathematical models aimed at the selection of variants of the natural potential development meeting the requirements of the equilibrium of natural resource management.

Acknowledgments

The study was prepared with the financial support of Russian Science Foundation (RSF) according to the research project № 14-18-00456 "Justification of the geological- ecological- social- and economic approach to the development of natural-resource potential of northern poorly known areas within the investment project "Arctic regions-Central Asia".

\section{REFERENCES}

1. Tatarkin A. I. 2015, Razvitie sistemnosti v osvoenii prirodnogo potentsiala severnykh maloizuchennykh territoriy [The development of systematization in the development of the natural potential of poorly explored northern areas], $317 \mathrm{p}$.

2. Tatarkin A. I., Ignatyeva M. N., Loginov V. G., Polyanskaya I. G., Yurak V. V. 2015, Ekologicheskie granitsy osvoeniya prirodno-resursnogo potentsiala Arkticheskoy zony RF v sovremennom sotsial'no-ekonomicheskom razvitii [Ecological borders of development of natural-resource potential of the Arctic zone of the Russian Federation in modern socioeconomic development]. Sovremennye proizvoditel'nye sily [Modern productive forces], no. 3, pp. 143-163.

3. Litvinova A. A., Ignatyeva M. N., Morozova L. M. 2015, Metodicheskie podkhody $\mathrm{k}$ obosnovaniyu sozdaniya seti osobo okhranyaemykh prirodnykh territoriy [Methodological approaches to justification of creating a network of protected areas]. Agrarnyy vestnik Urala Agrarian Bulletin of the Urals, no. 10. pp. 83-85.

4. Semyachkov A. I., Slavikovskaya Yu. O. 2015, Osobennosti geoekologicheskoy otsenki v ramkakh geoekosotsioekonomicheskogo podkhoda $k$ osvoeniyu severnykh territoriy [Features of geoecological estimation within geological- ecological- social- and economic approach to the development of the northern territories]. Ekonomika regiona - Economy of Region, no. 4, pp. 30-38. 5. Balashenko V. V., Ignatyeva M. N., Loginov V. G. 2015, Prirodno-resursnyy potentsial severnykh regionov: metodicheskie osobennosti kompleksnoy otsenki [Natural resource potential of northern regions: methodological features of complex estimation]. Ekonomika regiona Economy of Region, no. 4, pp. 84-94.

6. Ignatyeva M. N., Loginov V. G., Litvinova A. A., Balashenko V. V., Tseytlin E. M. 2015, Ukrupnennaya otsenka prognoziruemogo ekonomicheskogo ushcherba pri osvoenii mineral'no-syr'evoy bazy severnykh territoriy [The expanded evaluation of the predicted economic losses during the development of the mineral resource base of the northern territories]. Izvestiya Ural'skogo gosudarstvennogo gornogo universiteta - News of the Ural State Mining University, no. 4, pp. 84-87.

\author{
Aleksandr Ivanovich Tatarkin, \\ Dr, Member of the Russian Academy \\ of Sciences, Head of the Institute \\ of Economics of the Ural Branch of the RAS \\ tatarkin_ai@mail.ru \\ Valeriy Vasil'evich Balashenko, PhD, \\ Research Associate \\ Aleksej Vladimirovich Dushin, \\ $\mathrm{Dr}$, Assistant Professor \\ Margarita Nikolaevna Ignat'eva, \\ Dr, Professor \\ Albina Arkad'evna Litvinova, \\ $\mathrm{PhD}$, Senior Research Associate \\ Vladimir Grigoryevich Loginov, \\ Dr, Assistant Professor \\ Irina Gennad'evna Polyanskaya, \\ $\mathrm{PhD}$, Assistant Professor \\ Aleksandr Ivanovich Semyachkov, \\ Dr, Professor \\ Vera Vasil'evna Yurak, \\ postgraduate researcher \\ Institute of Economics of the Ural Branch \\ of the Russian Academy of Sciences, \\ Yekaterinburg, Russia
}

\author{
Yuliya Olegovna Slavikovskaya, \\ PhD, Senior Research Associate \\ Institute of Mining of the Ural Branch \\ of the Russian Academy of Sciences, \\ Yekaterinburg, Russia
}

